\title{
Development of The Assessment Instrument Based on HOTS on Explanatory Text Material and Film/Drama Reviews in Grade XI SMA Sultan Iskandar Muda Medan Academic Year 2017/2018
}

\author{
Rondang WK Sihotang \\ Education Of Indonesia Language,Post Graduate Program \\ The State University Of Medan \\ Medan, Indonesia \\ rondang93@gmail.com
}

\author{
Mutsyuhito Solin, Amrin Saragih \\ Education Of Indonesia Language,Post Graduate Program \\ The State University Of Medan \\ Medan, Indonesia
}

\begin{abstract}
The objectives of this study were (1) to develop the assessment instruments based on HOTS on explanatory text material and film / drama reviews in grade XI SMA, (2) the assessment instrument quality based on HOTS on explanatory text material and film / drama review in grade XI SMA. The type of this research was the first level of development research by Richey and Klein development model. The subjects of this study were the students of class XI SMA Sultan Iskandar Muda Medan, while the objects in this study were HOTS research assessment instruments on the text of research and drama, questionnaire validation by the expert, teachers response questionnaire, students response, and assessment sheet of the test on the object. Data analysis used descriptive analysis. The result of the research showed that (1) the assessment instrument product based on HOTS in book form, (2) validation result based on information below, (3) teachers response to the books was one of HOTS category which could be used for various categories. (4). This research helps teachers in assessing the level of consciousness.
\end{abstract}

Keywords- Development, Assessment Based on Hots, Explanatory Text and Movie / Drama Reviews

\section{INTRODUCTION}

Education can be conducted because of the learning that occurs through a process. The learning process that occurs in the classroom expects good learning outcomes. This learning result can be obtained from the assessment process carried out on students. The learning process requires a good, planned and continuous assessment system. Learning objectives can be achieved by conducting assessments that are supported by instruments that match the characteristics of the objectives (including competency standards and Basic Competencies), and are implemented periodically and continuously. The learning outcome assessment mechanism is written in the Ministerial Regulation of Minister of Education and Culture No. 53 of 2015 article 8 . The purpose of the assessment is to measure various skills in various contexts that reflect the situation in the real world where these skills are applied.
Therefore, educators must be able to consider what should be done by the students when they join various contexts that reflect the actual situation and apply it to their tasks. Assessment in the 2013 curriculum occurs through the learning process by using instrument tools, namely tests and non-tests. This research will develop an assessment instrument in the form of questions from the lesson plan.

Development of assessment instruments is to develop the existing instruments. This requires the researcher to have a sample of an instrument to be developed, so the researcher must conduct initial research into the school. Based on the observations that have been made at the Private Senior High School Of Sultan Iskandar Muda, Medan Sunggal which is one of the core schools targeted for the 2013 Curriculum by interviewing the school principal, Mr. Edy Jitro Sihombing, M.Pd stated that, "The 2013 curriculum has been implemented in this school for 9 semesters, but the implementation has not been fully implemented. The obstacle that impedes the performance of the teachers here is when developing assessment instruments. The obstacle which is experienced by the teachers is the lack of time in developing assessment instruments and the lack of understanding of the development of assessment instruments. Finally, it was done by writing descriptions without the right target. "

The process of the interviews conducted also experienced the same thing, namely when interviewing the class XI teacher in the Private Senior High School, Ms. Nasbiah stated, "The obstacle I experienced in this 2013 curriculum was in developing instruments, I did not know how to develop instruments, especially questions which are developed into the realm of $\mathrm{c} 4, \mathrm{c} 5$, and $\mathrm{c} 6$, but the school demanded to develop instruments, as a result the instruments produced were not suitable, and the students became slow in arguing because the instruments only required students to answer questions where the answers have been provided in the text .'

The above obstacles are also supported by the test instruments contained in the lesson plan of the school in 
Indonesian Language Subjects for Class XI of Senior High School (SMA 2) semester one for example in Film / Drama Review Text material that uses the ability to think C2 (Understanding) or low-level thinking skills (low order thingking). This can be seen in Basic Competencies. 3.2 and 4.2 (Comparing and producing film / drama texts both through oral and written) that is, the instrument does not require students to compare two film / drama review texts, in fact the students are instructed to discuss questions that refer only to one review text. Another obstacle found was that the absence of an assessment instrument in the form of a question that instructed to produce a film / drama review text, in fact only 7 items and the answer after that was directly to the attitude assessment. Basic Competencies in film / drama review texts that do not develop students' high-level thinking skills.

Similar events were also found in complex explanatory texts that use the ability to think $\mathrm{c} 1$, namely remembering or low-level thinking skills (low order thinking), can be seen in one of the Basic Competencies, that is Basic Competencies. 3.4 and 4.4 (Identifying and abstracting complex explanatory texts both orally and in written.)

The questions which are contained in the figure above indicate the meaning that students only rewrite the words contained in the explanatory text provided. Another fact of the problem above is, even though it uses analytical verbs, but this verb does not require students to think high, but only remembers how it is a complex explanatory text structure and grouping several paragraphs according to the place contained in the text provided.

The explanation of some of the obstacles above indicates that education thinking in schools today, especially in senior high school, has not been handled properly so that critical thinking skills in senior high school graduates are still relatively low. The low level of critical and creative thinking skills of graduates in elementary schools to universities in Indonesia are often complained (Reta, 2012: 4 in the Journal of Education, Vol. 26, No. 1).

The results of observations regarding the development of this assessment instrument were supported by Ningsih's research which said that "During this time there were found obstacles in the implementation of evaluations, especially seen from the mechanism of the assessment of learning outcomes, the development of assessment instrument items, and obstacles in applying assessment and determining techniques"(Citizenship Journal, Vol. 1 No. 2, January 2012). Based on the above opinion regarding the development of assessment instruments, it indicates that the school accompanist must provide direction to the teachers in developing assessment instruments, this is also supported by the Head of Surakarta State Senior High School 5, revealing that the school had held a 2013 curriculum assessment system workshop with the aim that is, "To improve the ability of teachers to develop assessment instruments and implement them in carrying out assessment tasks. In addition, it increases the ability of teachers to manage assessment results to report student learning outcomes (Himawan, 2013: 1 in the Journal of Inquiry, Vol. 5, No. 2, 2016, pp. 8-19).
The assessment instruments that are well designed and in accordance with the level of thinking ability can improve students' thinking, especially high-level thinking. In particular, Tran Vui (2001) in Rosnawati (2009: 3) defines high-level thinking abilities as follows: "Higher order thinking occurs when a person takes information and information stored in memory and interrelates and extends and extends this information to achieving a purpose or finding possible answers in perplexing situations ". Learning instruments that are oriented towards higher-order thinking skills are important to be developed because of the advancement of science and technology. This is in line with the opinion of Richmond (2007, in the Journal of Chemical Education Innovation, Vol. 8, No.2, 2014: 1383) in his research which states that good thinking skills can be strong capital for students in Asia to be able to face complex problems that exist in the development of modern times. Based on this, research will be conducted related to the development of HOTS-based assessment instruments.

\section{LITERATURE REVIEW}

Measuring and evaluating the success of learning can be done through tests. According to Bahri (2006: 106), based on the purpose and scope of the test can be classified into several types of types of assessment, namely: (1) Formative tests (2) Sumative tests, and (3) Submissions tests. According to Uno (2012: 110) tests of learning outcomes for research purposes need to pay attention to the following:

a. The test serves to obtain information about the ability of the research subjects. The assessment function aims to get about things that can be assessed through tests.

b. To determine assessment criteria for research. To do a good assessment, the question must be of good quality.

c. To design the questions that will be given to the research subject. The questions designed must be relevant to the level of difficulty and learning objectives set in the learning design.

Based on the statement above, the researcher must know how to write test instruments well as stated by Surapranata, (2005: 179-193) describing the principles of good writing, namely:

(1) the question must be in accordance with the Basic Competencies and indicators contained in the curriculum, (2) the choice of answers must be functioning, homogeneous, and logical, (3) each question must have one correct or correct answer, (4) the subject matter must be explained clearly and firmly, (5) the formulation of the subject matter and the choice of answers must be a necessary statement only, (6) the subject matter does not give directions to the correct answer, (7) the subject matter does not contain double negative statements, ( 8) pictures, graphs, tables, diagrams, and the like contained in the questions must be clear and functioning, (9) the length of the formulation of the answer choices must be relatively the same, (10) answer choices do not contain statements, "all of the above, wrong answers", or "all of the answers above, right", (11) answer choices in the form of numbers or time must be arranged in the order of the value of the number, or 
timed chronology, (12) items do not depend on the answers to the previous questions, (13) each question must use language in accordance with Indonesian language rules, (14) use communicative language so that it is easy to understand, (15) do not use applicable local language, if the questions will be used for other regions or nationally, and (16) the choice of answers do not repeat words or phrases that are not a unified understanding. Put the word on the subject matter.

According to Harjanto (2006: 280-281) written test forms that are often used in teaching and learning are divided into two, namely: description tests and objective tests. A description test is a test in the form of a written statement whose answer is a long description or sentence. The length of a short answer is relative, depending on the ability of the respondent to test.

This research will make a test instrument in the form of a description, therefore the following conditions must be known to make a test description instrument and how to assess it. Some circumstances that need to be considered in preparing the questions are among others, namely:

a. The question clearly measures the learning outcomes that students must master.

b. Using materials in preparing the question.

c. Beginning with the words explain, describe, specify, distinguish and so on.

d. Formulate the question clearly, so that it does not cause double meaning for students.

e. Adjust the short length and complexity of the answer to the level of maturity of students.

f. Write down a set of general instructions for the test.

Based on the statement above, then you must understand the rules to assess the description questions as follows:

a. The answers of descriptions should be assessed according to the learning outcomes measured.

b. Make the answer key as a guide in scoring.

c. The Score should be done by comparison method with comparison method with the use of predetermined criteria as a guidance..

d. Evaluate all students' answers to questions, not students for students.

\section{A. High Order Thingking Skills (HOTS)}

Higher Order Thinking Skills are students' thinking patterns by relying on the ability to analyze, create, and evaluate all aspects and problems. Brookhart (2010a: 5; 2010b: 7; 2010c: 99, in the EduMa Journal, Vol. 3, No. 2, 2014; 109), defining high-level thinking skills is,

"In this introduction, we consider the kinds of higher-
order thinking that are (or should be) stated or implied
in state content standards and classroom learning
objectives. Definitions that I find helpful fall into three
categories: 1) those that define higher-order thinking in
terms of transfer, 2) those that define it in terms of
critical thinking, and 3) those that define it in terms of
problem solving. Transfer: higher-order thinking is
conceived as students being able to relate their learning to other elements beyond those they were tought to associate with it Critical thinking: in the sense of reasonable, reflective thinking focused on deciding what to believe or do (Norris \& Ennis, 1989 dalam Susan M. Brookhart) is another general ability that is sometimes described as the goal of teaching. Problem solving: the nonautomatic strategizing required for reaching a goal (Nitko \& Brookhart, 2007 in Susan M. Brookhart) can also be seen as a broad goal of education. Bransford and Stein (1984) dalam Susan M. Brookhart), classified problem-solving skills a five-stage process called the IDEAL Problem Solver: 1) identify the problem, 2) define and represent the problem, 3) explore possible trategies, 4) act on the strategies, and 5) look back and avaluate the effects of your activities".

According to Uno (2012: 20), HOTS has four indicators, namely:

1. Problem solving or process in finding problems and ways to solve problems based on real information, so that conclusions can be drawn.

2. Decision-making skills, namely a person's skills in solving problems through information gathering, then choose the best decision in solving problems.

3. Critical thinking skills are attempts to find accurate information that is used as it should on a problem.

4. Creative thinking skills, which means generating many ideas so as to produce new innovations to solve problems.

Thus, HOTS impacts learning for students and teachers, namely: (1) learning will be more effective with higher order thinking; (2) increase the intellectual ability of teachers in developing higher order thinking; (3) in evaluating learning with this new concept, the teacher must always prepare questions that will not be answered simply. Indicators for measuring Higher Order Thinking Skills include analyzing skills (C4), evaluating (C5), and creating (C6) (Anderson \& Krathwohl, 2001 in Winarso, 2014, EduMa Journal, Vol. 3, No.2, 2014: 110).

\section{B. Film / Drama Review Text Structure and Rules}

The review text has four forming structures, namely; orientation, content interpretation, evaluation and summary.

1. Orientation

The orientation section contains a general description, introduction and views that underlie the mind in a literary work that will be reviewed. The initial section which contains the introduction of a literary work that contains the name, usefulness, background, place, time or short information and prefixes to enter the next stage.

2. Interpretative recount 
The Interpretative recount contains the views of his own reviewers regarding the work to be reviewed. This section is done after evaluating the work or item. In this section the author usually compares the work with other works that are considered similar. The author also assesses the strengths and weaknesses of the work that will be reviewed.

3. Evaluation

In this section, an assessment of the work, appearance and production is carried out. This section contains a detailed description of a work or item that was reviewed. Giving decisions about the value of a work that may be seen in terms of goals, ideas, values, and quality of work.

4. Evaluative summation

The author provides a final review in the form of the conclusion of the work. If described in the form of a chart.

\section{Explanatory Text}

The explanatory text has a social function to explain the process of occurring something according to the principle of causation. Dirgeyasa (2016: 84), "explanation genre is to explain the processes involved in the formation or working of natural or socio-cultural phenomena." The explanation genre is to explain the processes involved in the formation or process of natural or socio-cultural phenomena. The purpose of explanatory text according to Blake Education (2006: 50), quoted as follows:

An explanation is written to explain how and why something in the world happens. It is about actions rather than about things. Explanations play a valuable role in building and storing our knowledge. Technical and scientific writing are often expressed in this form. When writing explanations we establish that the phenomenon exists and then explain why or how this came about. The writer should acquire a great deal of content knowledge before beginning the explanation.

Kosasih (2014: 191), the important thing that needs to be the main concern in compiling the explanatory text is that the explanatory text is a text that explains a phenomenon, whether it is related to nature, culture and social. The development can be chronological or causal. Based on the description above, it can be concluded that the explanatory text is one type of text which contains the process of occurrence of an event both natural events, as well as social events and in the text the cause and effect of an event is explained in detail.

The explanatory text will not be formed without the structure and linguistic rules that shape it. Ministry of Education and Culture (2014: 9), the structure of the explanatory text consists of general statements and sequences of natural causes / order of social causes. The parts become the building of the explanatory Text as indicated in the following figure.

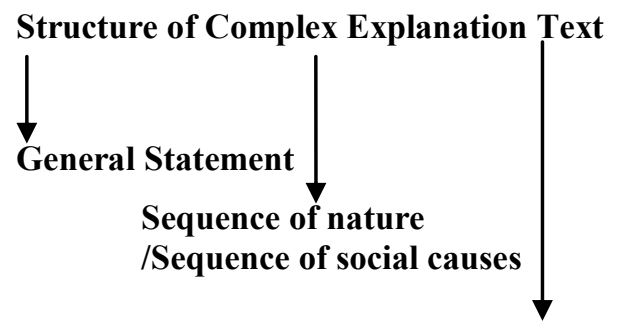

\section{Sequence of nature \\ /Sequence of social causes}

The Linguistic rules of explanatory text according to the Ministry of Education and Culture (2014) consists of (1) conjunction; (2) verb; (3) nouns; (4) complex clauses and simplex clauses; and (5) term word.

\section{RESEARCH METHODS}

This development research was carried out at Sultan Iskandar Muda Senior High School Medan which is located on the street of Tengku Amir Hamzah Pekan I Sunggal, MedanSunggal. The research was conducted in the even semester of the 2017/2018 school year, regarding the film review text material/drama and explanatory text material. The subjects of this study were students of class XI. This study is developmental research. The object of this research is the product of developing of HOTS-based assessment instruments. In the end, the product of this research instrument will be evaluated based on the aspects and quality of the products, which have been determined. Therefore, it is expected to be a product that meets the perfect criteria and is suitable for use. The development model used in this study is Richey and Klein.

\section{RESUlts AND Discussion}

The development product that was carried out in this research was HOTS-based assessment instrument, in the form of a book which became a guide for the teacher in making and implementing HOTS-based assessment in learning. The development of HOTS-based assessment instrument products were developed based on the existing test instruments in the learning implementation plan, then developed by applying HOTS. Furthermore, HOTS-based assessment instrument products were developed in the film/drama review texts and complex explanatory texts for the senior high school of class XI in book form. This product was then validated by 1 instrument expert lecturer, 1 material lecturer and Indonesian language teacher and 2 expert design lecturers.

The results of validation by validators and practitioners on the aspects of language questions, material questions and the construction questions based on the mean value of $90.50 \%$ were declared suitable for use in the field with the revision and very good categories. Based on the products that have been validated by experts and practitioners, involving 2 Indonesian language teacher of senior high school. Then, to find out the teachers' responses to the developed product were presented a 
questionnaire, where the teachers gave an assessment by using $(\sqrt{ })$ in the assessment column to consider the assessed aspects, namely : presentation techniques, ease of implementation, material suitability and language suitability. From the data collected regarding the teachers responses, the products developed were suitable for use in the field with revisions. The results of the assessment of the teachers responses obtained the average value of all aspects of assessment $93.60 \%$ with very good categories.

The end of the feasibility of this product by testing it in the field or in the class XI of Senior High School of Sultan Iskandar Muda Medan, located on the street of Tengku Amir Hamzah Pekan I Sunggal, Medan-Sunggal. Researchers acted as HOTS-based appraisers and as well as the Senior High School teachers of class XI acted as assessors. The implementation of the first feasibility test was still a lot that might be corrected with revisions. After discussing with the students, the teachers of class XI, the next a second feasibility test conducted in the class XI whereas the teachers remained as the assessors.

Based on the teachers' assessment of the second feasibility test conducted in the class XI of Senior High School, the average score was $94.40 \%$ with very good categories, and suitable for use in the field.

\section{CONCLUSIONS AND RECOMMENDATIONS}

\section{A. Conlusions}

Based on the formulation, objectives, results and discussion in the research on the development of HOTS-based assessment instruments regarding the material of the film/drama review text and complex explanatory text at the class XI of Senior High School of Sultan Iskandar Muda Medan can be summarized as follows:

- HOTS-based assessment instrument products on film/drama review texts and complex explanatory texts for class XI of Senior High School students were developed based on pre-existing instruments and developed by applying HOTS, then use the Richey and Klein development model.

- The quality of this instrument is obtained from the results of the validation carried out, the responses of the teachers, and the test of the feasibility of the product. Validation conducted by the validator on each aspect of language assessment questions, material questions and construction question, as a whole can be stated that the HOTS-based assessment instrument products are suitable for use in the field with revisions, in which the categories are very good. The teachers' responses to HOTS-based assessment instrument products on the material of film/drama review and complex explanatory text in the class XI of Senior High School students, from each aspect of the overall assessment was declared to be feasible to use in the field with revisions, in which the categories are very good. The test of the feasibility of HOTS-based assessment instrument products on the material of film/drama review and complex explanatory text for Senior High School students in the first feasibility test field still had problems, especially in the implementation aspects of HOTS-based instrument products. The second test of eligibility requirements can be fulfilled, especially in the implementation of assessment of HOTS-based instrument products, thus the HOTS-based assessment instrument products are suitable for use.

\section{B. Recommendations}

This HOTS-based assessment book has just arrived at the development stage, it has not been widely implemented in other schools, its spread is limited in subjects at the research school. Teachers and researchers can implement on a wider scope in schools to get feasibility. This HOTS-based assessment book can be used by teachers as an alternative in implementing HOTS-based assessment instruments in Senior High Schools that have implemented the 2013 curriculum.

\section{REFERENCES}

(1) Agustyaningrum, Nina. Mengembangkan Keterampilan Berpikir Tingkat Tinggi Dalam Pembelajaran Matematika Smp. Jurnal Phytagoras, Vol. 4, No. 1, 2015:39-46

(2) Amalia, Nunung Fika., Endang Susilaningsih. 2014. Pengembangan Instrumen Penilaian Keterampilan Berpikir Kritis Siswa Sma Pada Materi Asam Basa. Jurnal Inovasi Pendidikan Kimia, Vol. 8, No. 2, 2014:1380-1389

(3) Ariandari, Weindy Pramita. Mengintegrasikan Higher Order Thinking Dalam Pembelajaran Creative Problem Solving. Prosiding:Seminar Nasional Matematika Dan Pendidikan Matematika.Uny, 2015:489-496

(4) Arikonto, Suharsimi. 2003. Manejemen Penelitian .Jakarta:Rineka Cipta.

(5) Arikunto, Suharsimi. (2004). Dasar-Dasar Evaluasi Pendidikan. Jakarta: Bumi Aksara

(6) Bahri Djamarah, Syaiful. 2006. Guru dan Anak Didik dalam Interaksi Edukatif. Jakarta: Rineka Cipta

(7) Blake Education. 2006. Targeting Text: Information Report, Explanation, Discussion, Upper level. Singapore: Green Giant Press

(8) Brookhart, Susan. M. 2010. "How to Assess HigherOrder Thinking Skills in Your Class Room". USA : ASCD Alexandria, Virginia USA

(9) Dirgeyasa, Wy. 2016. College Academic Writing A Genre Based Perspective. Jakarta: Peranada Media Group

(10) Harjanto, 2006. Perencanaan Pembelajaran. Jakarta : Rineka Cipta

(11) Kemendikbud. 2014. Kurikulum 2013, Standar Kompetensi Dasar Sekolah Menengah Atas (SMA)/Madrasah Aliyah(MA). Jakarta.

(12) Kosasih, E. 2014. Jenis-Jenis Teks. Bandung. Yrama Widya 
(13) King, F. J., Goodson, L., Rohani, F. (2004). Higher Order Thinking Skill. A publication of the Educational Services Program, now known as the Center for Advancement of Learning and Assessment.

(14) Ningsih, Nuroktya . 2012. Hambatan Guru Pendidikan Kewarganegaraan dalam Pelaksanaan Evaluasi Pembelajaran di SMAN 1 Sanden. Jurnal Citizenship, Vol. 1, No.2, 2012:123-132

(15) Nurjananto, Nino dan Kusumo, Ersanghono. 2015. Pengembangan Instrumen Penilaian Autentik Untuk Mengukur Kompetensi Peserta Didik Materi Senyawa Hidrokarbon. Jurnal Inovasi Pendidikan Kimia, Vol 9, No. 2, 2015, hlm 1575 - 1584.

(16) Peraturan Pemerintah Nomor 19 Tahun 2005 tentang Standar Nasional Pendidikan. 2010. Bandung

(17) Redhana, I W. \& Liliasari.2008a. Program Pembelajaran Keterampilan Berpikir Kritis pada Topik Laju Reaksi untuk Siswa SMA. Forum Kependidikan, 27(2): 103112.

(18) Reta, I. K., 2012, Pengaruh Model Pembelajran Berbasis Masalah terhadap Keterampilan Berpikir Kritis Ditinjau dari Gaya Kognitif Siswa, Jurnal Pendidikan, Vol 26, No 1, Hal: 1-16.
(19) Richey, Rita C. Klein. 2007. Design and Development Research. London: Lawrence Erlbaum Associates. Inc.

(20) Rosnawati, R. 2009. Enam Tahapan Aktivitas Dalam Pembelajaran Matematika Untuk Mendayagunakan Berpikir Tingkat Tinggi Siswa. Prosiding, Seminar Nasional Dengan Tema: "Revitalisasi Mipa Dan Pendidikan Mipa Dalam Rangka Penguasaan Yogyakarta

(21) Surapranata, Sumarna. 2005. Panduan Penulisan Tes Tertulis Implementasi Kurikulum 2004. Bandung: Remaja Rosdakarya

(22) Uno, Hamzah. 2012. Assesment Pembelajaran. Jakarta: Bumi Aksara

(23) Widowati, Tutut Widowati, Nonoh Siti Aminah. 2016. Pengembangan Instrumen Penilaian Otentik Berbasis Scientific Literacy Pada Pembelajaran Fisika Di Sma Sebagai Implementasi Kurikulum 2013. Jurnal Inkuiri, Vol. 5, No. 2, 2016:8-19

(24) Winarso, widodo. 2014. Membangun Kemampuan Berfikir Matematika Tingkat Tinggi Melalui Pendekatan Induktif, Deduktif dan Induktif-Deduktif Dalam Pembelajaran Matematika. Jurnal: EduMa. Vol. 3, No. 2, Desember 2014:95-118 